\title{
QUALITY OF SERVICE TO CUSTOMER SATISFACTION AND LOYALTY TO THE ONLINE TRANSPORTATIONS (GOJEK) IN INDONESIA POST-PANDEMIC COVID-
}

\author{
WAHYU ADHI YATMA ${ }^{1}$, ERRY RIMAWAN ${ }^{2} \&$ ANTONIUS SETYADI $^{3}$ \\ ${ }^{1,2}$ Master of Industrial Engineering Program, Mercu Buana University, Jakarta, 10340 Indonesia \\ ${ }^{3}$ Master of Management Program, Mercu Buana University, Jakarta, 10340 Indonesia
}

\begin{abstract}
The existence of covid-19 brings any changes in this world. All industries around us experience a significant impact. Many industries end up closing down companies or firing employees because of the losses that have been caused by the spread of the covid-19 virus. Keeping physical distancing and not leaving the house if it is not important is a solution to breaking the chain of distribution of covid-19 which has claimed many lives around the world, including in Indonesia. However, such regulations become a big loss for online transportation, especially motorcycle taxy or what is often called an "ojek". Keeping a distance for ojek is not easy because every day they are dealing directly with consumers. The threat of covid-19 virus transmission is not averted by calls for cleanliness and the use of masks carried out when the covid-19 virus enters Indonesia until the enactment of Large-Scale Social Restrictions similar to Lock Down but there is still economic activity with certain requirements. With the data generated service quality has a positive effect on customer satisfaction 0.673 and service quality has a positive effect on customer loyalty 0.524 . With an average value of Reliability service quality with a value of 4.23 (84.6\%), then Tangible 4.12 (82.4\%), Responsiveness 4.01 (80.2\%), Assurance 3.96 (79.2\%), Empathy 3.83 (76.6\%).
\end{abstract}

KEYWORDS: SEM-PLS, Service Quality, Customer Satisfaction, Customer Loyalty, Online Transportation, Motorcycle Taxi, Covid-19

Received: Jun 08, 2020; Accepted: Jun 28, 2020; Published: Aug 11, 2020; Paper Id.: IJMPERDJUN2020737

\section{INTRODUCTION}

The impact of the covid-19 virus has the effect of disrupting the economy in all countries including Indonesia. Developing startups contribute to the decline in the economy. GoJek companies(Indonesian native applicationbased industry engaged in online transportation services), especially GoRide, have a very big impact because of the rules of keeping distance to consumers which results in not being allowed to take passengers in any form. The loss of the main source of income for GoRide partners is in line with the satisfaction and loyalty of GoJek customers, especially in passenger delivery services. "Ojek" or motorcycle taxi online at this time is really needed at this time because the solution to avoid traffic jams and relatively cheap prices. With the entry of covid-19 virus into Indonesia will affect customer satisfaction or not. Looking for solutions how customer satisfaction and loyalty is maintained in the midst of the co-19 pandemic is the answer with the goal that GoRide can move back with protocols that are believed to be safe to avoid and cut off the spread of covid-19. 


\section{LITERATURE REVIEW}

The conceptual definition of service quality developed by Parasuraman et al., (1988) has largely been used to compare excellence in service relationships with customers. Bitner (1990) defines service quality as the overall impression of the customer from the relative inferiority / superiority of the service provider and is often considered to be similar to the overall attitude of the customer towards the company. The definition of service quality includes several points. One of them is the attitude developed over all previous relationships with service companies (Bitner, 1990; Parasuraman et al., 1985, 1988).

Parasuraman et al., (1988) also identified five dimensions of service quality (reliability, responsiveness, assurance, empathy, and tangibles) that connect certain service characteristics with consumer expectations:

- Reliability, namely the ability to provide services in accordance with the promises offered

- Responsiveness, which is the response or alertness of employees in helping customers and providing services that are fast and responsive

- Assurance, including the ability of employees to appropriately know product, the quality of hospitality, attention and courtesy in providing services, skills in providing information, skills in providing security in utilizing the services offered, and the ability to instill customer trust in the company.

- Emphaty, namely individual attention given by the company to customers such as the ease of contacting the company, the ability of employees to communicate with customers, and the company's efforts to understand the wants and needs of its customers.

- Tangibles, including the appearance of physical facilities such as buildings and front office rooms, the availability of parking lots, cleanliness, neatness and comfort of the room, the completeness of communication equipment, and the appearance of employees.

To be able to measure the level of customer satisfaction, then we need some dimensions to measure that satisfaction. According to Kotler and Keller (2009) dimensions of customer satisfaction are: suitability of expectations, customer expectations regarding the speed of service provided, performance perceptions, customer ratings, customer experience, total satisfaction.

Gremler and Brown (1996) state the definition of customer loyalty is the extent to which the customer repeats the buying behavior of the service provider, has a positive disposition towards the provider, and considers only using this provider when service is needed. According to Bloemer and Kasper (1995), loyalty is defined as true loyalty compared to repeated buying behavior, which actually repurchases a brand, regardless of commitment. Zeithaml et al., (1996) stated that loyalty is a multi-dimensional construct and includes positive and negative responses.Buttle (2007) defines and measures loyalty in two ways, based on customer behavior and attitude:

- Behavioral loyalty, measured by customer buying behavior as indicated by the high frequency of customers coming to a store or buying a product. The most loyal customers are those who get the highest score on three variables, namely recency of purchase $(R)$, frequency of purchase $(F)$, and what monetary value of purchase (M). The three variables are measured in the following way: 
$\mathbf{R}=$ The length of time interval since they last bought

$\mathbf{F}=$ Frequency of purchases made within a certain period

$\mathbf{M}=$ The amount of money they spend in a certain period.

- Attitudinal loyalty is measured by referring to attitude components, such as beliefs, feelings, and will to make a purchase, according to Dick and Basu in Francis Buttle (2007), "truly loyal consumers are those who have high frequency of repurchases and show attitudes faithful strong ".

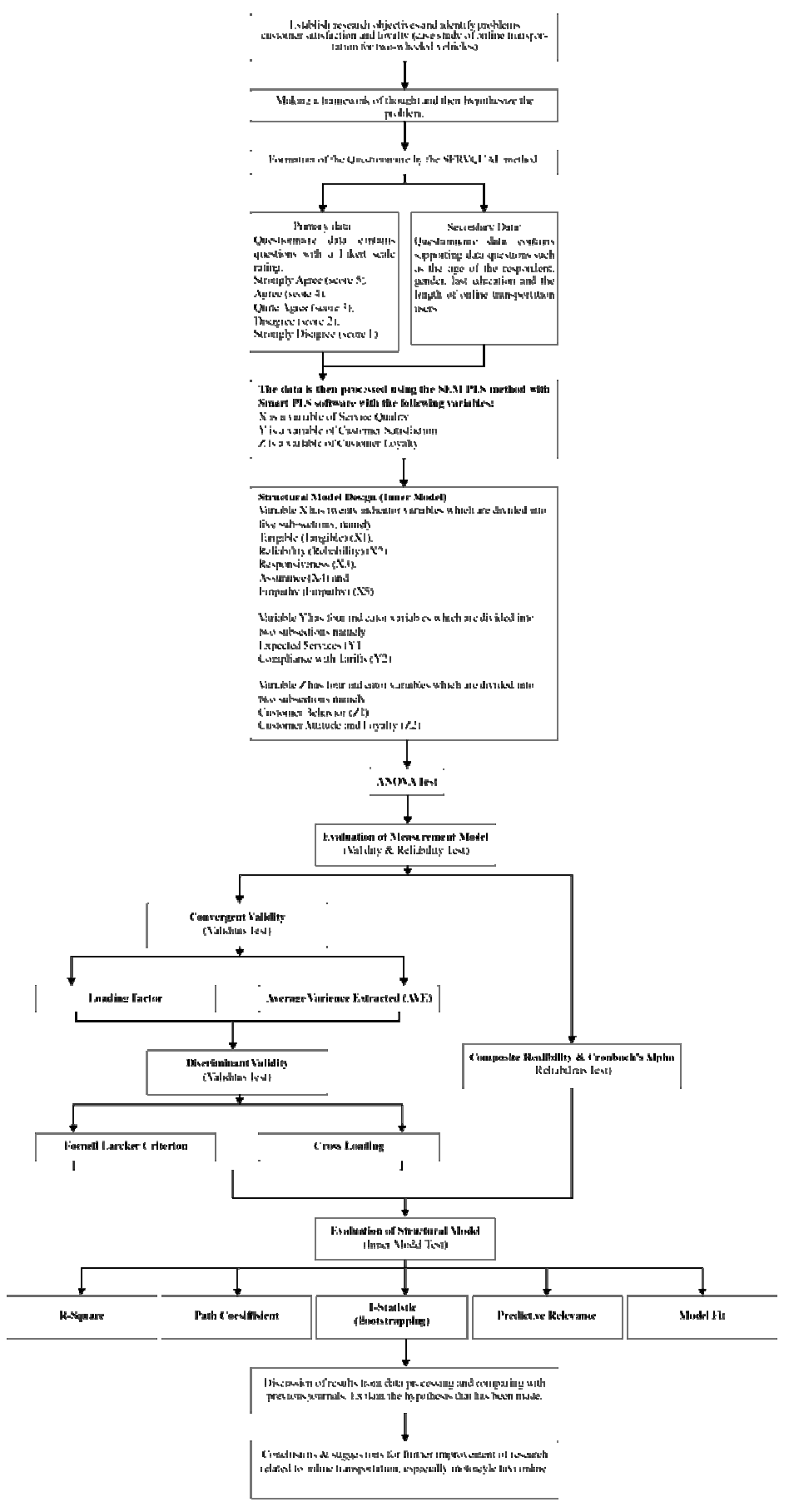

Figure 1: The Researh Process. 


\section{REASEARCH METHODOLOGY}

We conducted a qualitative and quantitative approach in the form of an online questionnaire with a total of 129 respondents who were asked questions related to the quality of online motorcycle taxi services with five SERVQUAL dimensions at the time of the co-19 virus pandemic. The entire research process will be carried out and illustrated in Figure. 1. Using multivariate analytical methods aims to analyze the data obtained from the survey using the one-way ANOVA method to find the average then use structural modeling equation modeling (SEM-PLS) techniques with the help of Smart-PLS software where each variable provides valid information. The data collected in the form of qualitative data using a Likert scale to get the values that will be processed later.

Researchers also propose a research model based on the SERVQUAL model to determine the determinants of service quality on customer satisfaction and loyalty of GoRide users when the co-19 virus pandemic.

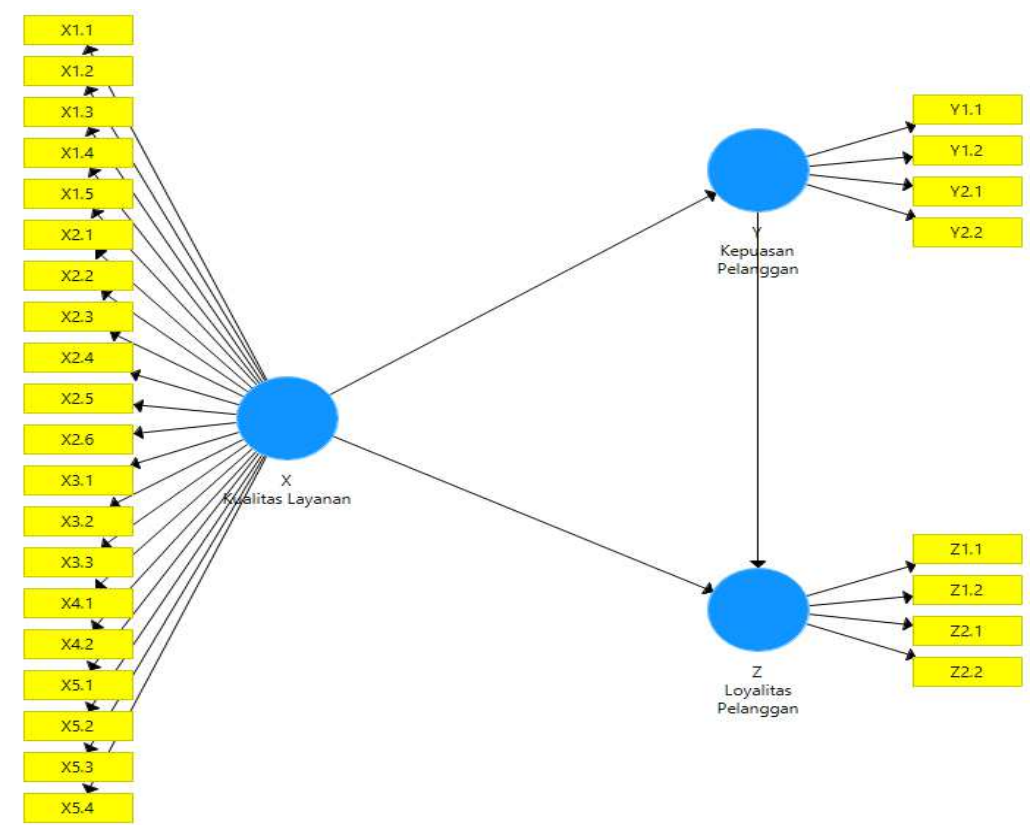

Figure 2: Proposed Research Model.

\section{Hipotesis Penelitian}

- H1: X_Quality of Service has a positive impact on Y_Customer Satisfaction

- H2: X_Quality of Service has a positive impact on Z_Customer Loyalty

- H3: Y_Customer Satisfaction has a positive impact on Z_Customer Loyalty

\section{RESULT AND DISCUSSIONS}

\section{Result}

From the distribution of questionnaires there were 129 respondents with different backgrounds according to the format determined by the researcher. 
Table 1: Characteristics of Respondents

\begin{tabular}{|c|c|c|}
\hline Gender & Respondents & Percentage \\
\hline Man & 49 & $38 \%$ \\
\hline Woman & 80 & $62 \%$ \\
\hline Total & 129 & $100 \%$ \\
\hline Age & Respondents & Percentage \\
\hline $17-30$ & 91 & $70,5 \%$ \\
\hline $31-40$ & 32 & $24,8 \%$ \\
\hline $41-50$ & 5 & $3,9 \%$ \\
\hline$>50$ & 1 & $0,8 \%$ \\
\hline Total & 129 & $100 \%$ \\
\hline Education & Respondents & Percentage \\
\hline Middle School & 2 & \\
\hline High School & 34 & $26,4 \%$ \\
\hline Diploma & 23 & $17,8 \%$ \\
\hline Bachelor & 56 & $43,4 \%$ \\
\hline Graduate & 14 & $10,8 \%$ \\
\hline Postgraduate & 0 & $0 \%$ \\
\hline Total & 129 & $100 \%$ \\
\hline Duration of GoRide & Respondents & Percentage \\
\hline 1 Years & 13 & $10,1 \%$ \\
\hline 2 Years & 40 & $31 \%$ \\
\hline 3 Years & 33 & $25,6 \%$ \\
\hline 4 Years & 23 & $17,8 \%$ \\
\hline$>5$ Years & 20 & $15,5 \%$ \\
\hline Total & 129 & $100 \%$ \\
\hline
\end{tabular}

After collecting secondary data, then proceed with premier data processing. At this initial stage the researchers conducted an ANOVA test to find the average of each service quality variable using the one way method and produce a significant value in table 3 using the SPSS application.

Table 2: Descriptive

\begin{tabular}{|l|c|c|c|c|c|c|}
\hline & N & Mean & Std. Deviation & Std. Error & Min & Max \\
\hline Tangible & 645 & 4,12 &, 842 &, 033 & 1 & 5 \\
\hline Reliability & 774 & 4,23 &, 803 & 0,29 & 1 & 5 \\
\hline Responsiveness & 387 & 4,01 &, 842 & 0,43 & 1 & 5 \\
\hline Assurance & 258 & 3,96 &, 753 & 0,47 & 2 & 5 \\
\hline Empathy & 516 & 3,83 &, 858 & 0,38 & 1 & 5 \\
\hline Customer Satisfaction & 516 & 2,99 & 1,051 & 0,46 & 1 & 5 \\
\hline Customer Loyalty & 516 & 3,87 &, 939 &, 016 & 1 & 5 \\
\hline
\end{tabular}

Table 3: One Way ANOVA

\begin{tabular}{|l|c|c|c|c|c|}
\hline & Sum of Squares & df & Mean Squares & F & Sig. \\
\hline Between Groups & 553,762 & 6 & 92,294 & 126,432 &, 000 \\
\hline Within Groups & 2631,600 & 3605 &, 730 & & \\
\hline Total & 3185,362 & 3611 & & & \\
\hline
\end{tabular}

The average Tangible, Reliability, Responsiveness variables are included in the "satisfied" category, while in Assurance and Empathy the scores are "quite satisfied". Only the Assurance variable has a minimum value of "not satisfied" among the other variables.

To test the truth of the researcher's hypothesis, the researcher re-tested the value of the questionnaire by testing the SEM-PLS which was processed using the Smart-PLS version 3.0 applications. 


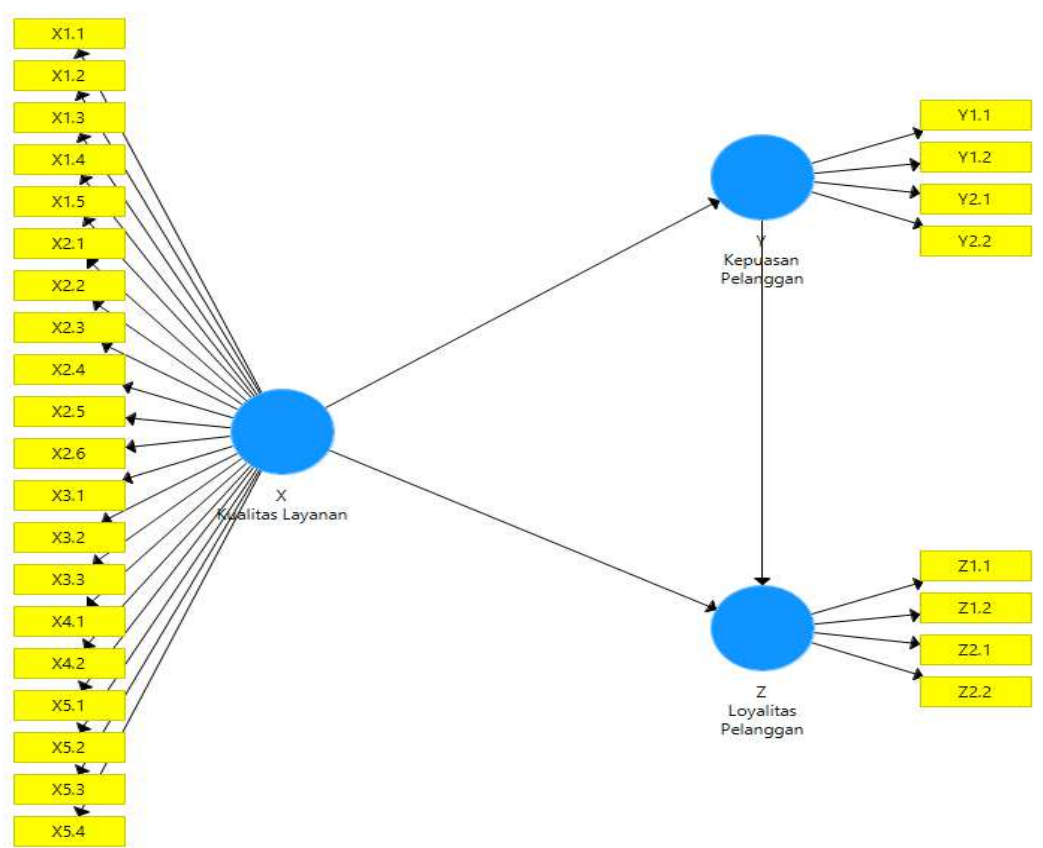

Figure 3: Model Framework on Smart PLS.

The first step taken is the Loading Factor process which is a value generated by each indicator to measure a variable with a value limit of 0.7 .

Table 4: Loading Factor

\begin{tabular}{|c|c|c|c|c|}
\hline & X_Quality of Service & Y_CustomerSatisfaction & Z_CustomerLoyalty & Evaluation \\
\hline $\mathrm{X} 1.1$ & 0.502 & & & Invalid \\
\hline $\mathrm{X} 1.2$ & 0.763 & & & Valid \\
\hline $\mathrm{X} 1.3$ & 0.672 & & & Invalid \\
\hline $\mathrm{X} 1.4$ & 0.580 & & & Invalid \\
\hline $\mathrm{X} 1.5$ & 0.786 & & & Valid \\
\hline $\mathrm{X} 2.1$ & 0.768 & & & Valid \\
\hline $\mathrm{X} 2.2$ & 0.762 & & & Valid \\
\hline $\mathrm{X} 2.3$ & 0.566 & & & Invalid \\
\hline $\mathrm{X} 2.4$ & 0.525 & & & Invalid \\
\hline $\mathrm{X} 2.5$ & 0.720 & & & Valid \\
\hline $\mathrm{X} 2.6$ & 0.624 & & & Invalid \\
\hline $\mathrm{X} 3.1$ & 0.719 & & & Valid \\
\hline $\mathrm{X} 3.2$ & 0.802 & & & Valid \\
\hline $\mathrm{X} 3.3$ & 0.787 & & & Valid \\
\hline $\mathrm{X} 4.1$ & 0.734 & & & Valid \\
\hline $\mathrm{X} 4.2$ & 0.738 & & & Valid \\
\hline $\mathrm{X} 5.1$ & 0.832 & & & Valid \\
\hline $\mathrm{X} 5.2$ & 0.702 & & & Valid \\
\hline $\mathrm{X} 5.3$ & 0.642 & & & Invalid \\
\hline $\mathrm{X} 5.4$ & 0.733 & & & Valid \\
\hline Y1.1 & & 0.872 & & Valid \\
\hline $\mathrm{Y} 1.2$ & & 0.839 & & Valid \\
\hline Y2.1 & & 0.877 & & Valid \\
\hline $\mathrm{Y} 2.2$ & & 0.796 & & Valid \\
\hline $\mathrm{Z} 1.1$ & & & 0.825 & Valid \\
\hline Z1.2 & & & 0.877 & Valid \\
\hline $\mathrm{Z} 2.1$ & & & 0.821 & Valid \\
\hline $\mathrm{Z} 2.2$ & & & 0.698 & Invalid \\
\hline
\end{tabular}


Invalid indicators are then removed because they will affect the values of the veriable itself and cannot calculate every variable. These indicators include X1.1 (0.502), X1.3 (0.672), X1.4 (0.580), X2.3 (0.566), X2.4 (0.525), X2.6 (0.624), X5.3 (0.642) and Z2.2 (0.698). Indicators that have been deleted will affect the value of other variables that are violated in table 5 .

Table 5: Loading Factor Elimination of Indicators Less Than 0.7

\begin{tabular}{|l|c|c|c|l|}
\hline & X_Quality of Service & Y_Customer Satisfaction & Z_Customer Loyalty & Evaluation \\
\hline X1.2 & 0.780 & & & Valid \\
\hline X1.5 & 0.803 & & & Valid \\
\hline X2.1 & 0.783 & & & Valid \\
\hline X2.2 & 0.782 & & & Valid \\
\hline X2.5 & 0.703 & & & Valid \\
\hline X3.1 & 0.707 & & & Valid \\
\hline X3.2 & 0.804 & & & Valid \\
\hline X3.3 & 0.801 & & & Valid \\
\hline X4.1 & 0.747 & & & Valid \\
\hline X4.2 & 0.781 & & & Valid \\
\hline X5.1 & 0.852 & & & Valid \\
\hline X5.2 & 0.702 & & & Valid \\
\hline X5.4 & 0.739 & & & Valid \\
\hline Y1.1 & & & & Valid \\
\hline Y1.2 & & 0.874 & & Valid \\
\hline Y2.1 & & 0.837 & & Valid \\
\hline Y2.2 & & 0.877 & & Valid \\
\hline Z1.1 & & 0.796 & & Valid \\
\hline Z1.2 & & & & 0.894 \\
\hline Z2.1 & & & & Valid \\
\hline
\end{tabular}

Furthermore, testing to know whether each variable has a valid indicator or not in the process of Average Variance Extracted (AVE) is the value of each variable above 0.5.

Table 6: Average Variance Extracted (AVE)

\begin{tabular}{|l|c|l|}
\hline & Average Variance Extracted (AVE) & Evaluation \\
\hline X_Quality of Service & 0.592 & Valid \\
\hline Y_Customer Satisfaction & 0.717 & Valid \\
\hline Z_Customer Loyalty & 0.803 & Valid \\
\hline
\end{tabular}

And then testing R-Square, Path Coefficient, T-Statistic.

Table 7: R-Square

\begin{tabular}{|l|c|c|c|}
\hline & R Square & R Square Adjusted & Persentase R-Square \\
\hline Y_Customer Satisfaction & 0,453 & 0,449 & $45,3 \%$ \\
\hline Z_Customer Loyalty & 0,272 & 0,260 & $27,2 \%$ \\
\hline
\end{tabular}

Table 8: Path Coefficient

\begin{tabular}{|l|c|c|c|c|}
\hline & X_Quality of Service & Y_Customer Satisfaction & Z_Customer Loyalty & Evaluation \\
\hline X_Quality of Service & & 0.673 & -0.003 & Positive \\
\hline $\begin{array}{l}\text { Y_Customer } \\
\text { Satisfaction }\end{array}$ & & & 0.524 & Positive \\
\hline Z_Customer Loyalty & & & & \\
\hline
\end{tabular}


Table 9: T-Statistic

\begin{tabular}{|l|c|c|c|c|c|}
\hline & $\begin{array}{c}\text { Original } \\
\text { Sample (O) }\end{array}$ & $\begin{array}{c}\text { Sample } \\
\text { Mean (M) }\end{array}$ & $\begin{array}{c}\text { Standard } \\
\text { Deviation (STDEV) }\end{array}$ & $\begin{array}{c}\text { T Statistics } \\
(\mid \mathbf{O} / \text { STDEV]) }\end{array}$ & $\begin{array}{c}\text { P } \\
\text { Values }\end{array}$ \\
\hline $\begin{array}{l}\text { X_Quality of Service - } \\
\text { >Y_Customer Satisfaction }\end{array}$ & 0.673 & 0.680 & 0.058 & 11.662 & 0.000 \\
\hline $\begin{array}{l}\text { X_Quality of Service }- \\
\text { >Z_Customer Loyalty }\end{array}$ & -0.003 & -0.005 & 0.092 & 0.036 & 0.971 \\
\hline $\begin{array}{l}\text { Y_Customer Satisfaction - } \\
\text { >Z_Customer Loyalty }\end{array}$ & 0.524 & 0.526 & 0.087 & 6.016 & 0.000 \\
\hline
\end{tabular}

The percentage value of R-Square is very small $45.3 \%$ in Customer Satisfaction and $27.2 \%$ in Customer Loyalty can be interpreted as variables outside have a greater impact. In this final stage, testing is carried out on one variable to another with a minimum value of more than 1.96, then the variable is declared significant. Then the final results obtained are Quality of Service effect on Customer Satisfaction and Customer Satisfaction influence on Customer Loyalty get a significant and positive value (hypothesis accepted). While Quality of Service has an effect on Customer Loyalty, the value is not significant (hypothesis rejected), but it is still categorized positively in Path Coefficient testing. Then we can then see the final structural framework in Figure 2.

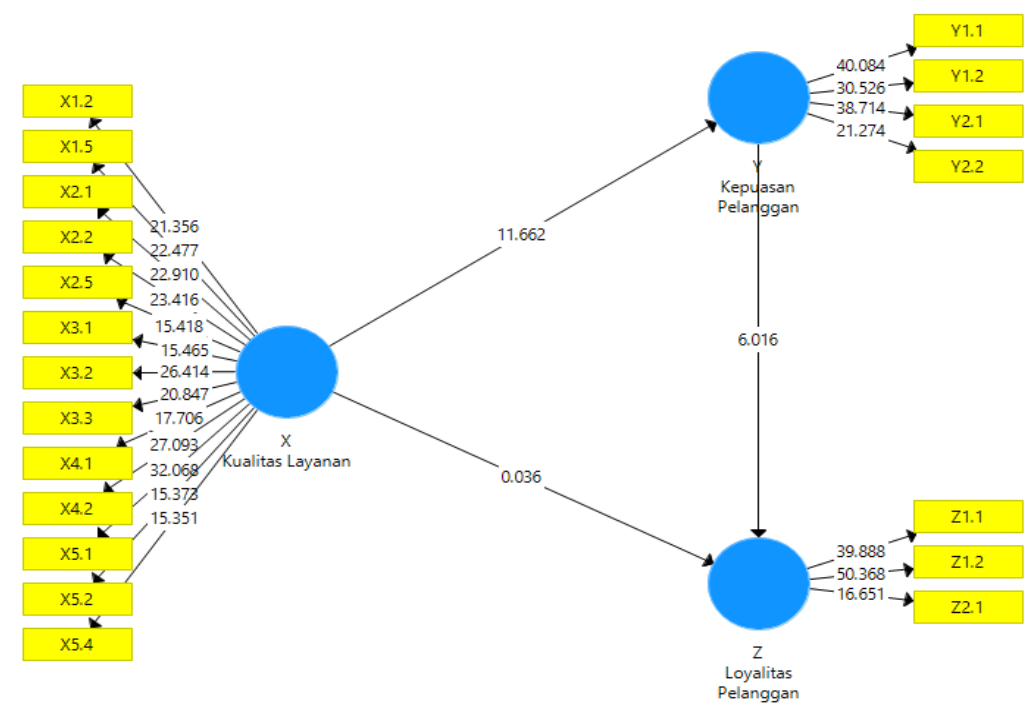

Figure 4: Model Framework on Smart PLS.

\section{DISCUSSION}

From the results of these tests the average value of the largest service quality on the variable reliability with a value of 4.23 (84.6\%), then manifested 4.12 (82.4\%), Responsiveness 4.01 (80.2\%), Collateral 3.96 (79.2\%), Empathy 3.83 (76.6\%). For Customer Satisfaction, the average value is 3.78 (75.6\%) and Customer Loyalty 2.99 (59.8\%). Means the reliability of the driver (Reliability) is more important than the provision of masks (Tangible) and others. With other support stating that the R-Square testing resulted in Customer Satisfaction 0.453 (45.3\%) and Customer Loyalty 0.272 (27.2\%). This proves that the other indicators outside of this variable that are owned are very large.

\section{CONCLUSIONS}

In this situation all roles must be involved, starting from the government, companies, online motorcycle taxi drivers and consumers in order to decide on the spread of the covid-19 virus. We know the government is trying to prevent and cure 
patients with the covid-19 virus. While online transportation companies make new rules which, as recommended by the government, provide action for violating online transportation drivers. Online motorcycle taxi drivers must comply with protocols that make consumers feel safe and comfortable when driving on the road. Consumers also have to remind themselves about educating the danger of covid-19 virus by prioritizing health rather than having to get to their destination on time. There will be segment changes going forward for consumers who are accustomed to clean living, while companies and online motorcycle taxi drivers make the pandemic covid-19 virus a new opportunity to increase customer satisfaction and loyalty.

In this study, take the sample respondents with high transportation activity precisely the border area with Jakarta (Indonesian capital) with the surrounding cities, precisely the Depok area, whose population actually has jobs in the capital. Depok is the first city in Indonesia to be known to have positive citizens infected with the covid virus - 19. This research still has many shortcomings, it could also be a reference for further research. The many limitations of conducting research such as the implementation of PSBB / Large-scale social restrictions (Almost the same as lock down with different rules) are the main obstacles in this study. Hopefully this research is also useful as information to the general public about the phenomenon occurring when the co-19 pandemic takes place.

\section{REFERENCES}

1. Anindhita, W., Arisanty, M., \& Rahmawati, D. (2016). Analisis Penerapan Teknologi Komunikasi Tepat Guna Pada Bisnis Transportasi Ojek Online (Studi pada Bisnis Gojek dan Grab Bike dalam Penggunaan Teknologi Komuniasi Tepat Guna untuk Mengembangkan Bisnis Transportasi). Universitas Bakrie, 2, 712-729.

2. Azizah, A., \& Adawia, P. R. (2018). Analisis Perkembangan Industri Transportasi Online Di Era Inovasi Disruptif (Studi Kasus Pt Gojek Indonesia). Cakrawala - Jurnal Humaniora, 18(2), 149-156. https://doi.org/10.31294/JC.V1812.4117

3. Bitner, M. J. (1990). Evaluating service encounters the effects of physical surroundings and employee responses. Journal of Marketing, 54(2), 69-82.

4. Bloemer, J. M. M., Kasper, H. D. P. (1995). The complex relationship between consumer satisfaction and brand loyalty. Journal of Economic Psychology, 16(2), 311-329.

5. Buttle, F. (2007). Customer Relationship Management Concept and Tools. Oxford: Elsevier Science.

6. Chang, S. E., Shen, W. C., \& Liu, A. Y. (2016). Why mobile users trust smartphone social networking services? A PLS-SEM approach. Journal of Business Research, 69(11), 4890-4895. https://doi.org/10.1016/j.jbusres.2016.04.048

7. Edvardsson, B., Johnson, M. D., Gustafsson, A., Strandvik, T. (2000). The Effects of Satisfaction and Loyalty on Profits and Growth- Products Versus Services. Total Quality Managment, 11(7), 917-927.

8. Farida, I., Tarmizi, A., \& November, Y. (2016). Analisis Pengaruh Bauran Pemasaran 7P Terhadap Kepuasan Pelanggan Pengguna Gojek Online. 1(1), 31-40.

9. Gremler, D. D., Brown, S. W. (1996). Service loyalty: its nature, importance and implications. Proceedings of American Marketing Association, (pp 170-180). Idaho, USA: Idaho University.

10. Hair, J. F., Howard, M. C., \& Nitzl, C. (2020). Assessing measurement model quality in PLS-SEM using confirmatory composite analysis. Journal of Business Research, 109(November 2019), 101-110. https://doi.org/10.1016/j.jbusres.2019.11.069 
11. Kautsarina, Hidayanto, A. N., Anggorojati, B., Abidin, Z., \& Phusavat, K. (2020). Data modeling positive security behavior implementation among smart device users in Indonesia: A partial least squares structural equation modeling approach (PLSSEM). Data in Brief, 105588. https://doi.org/10.1016/j.dib.2020.105588

12. Kim, W., Kim, H., \& Hwang, J. (2020). Sustainable growth for the self-employed in the retail industry based on customer equity, customer satisfaction, and loyalty. Journal of Retailing and Consumer Services, 53(February 2019), 101963. https://doi.org/10.1016/j.jretconser.2019.101963

13. Kotler, P., Keller, K. L. (2009). ManajemenPemasaran. Jakarta: Gramedia

14. Laurent, F. (2016). Pengaruh E-Service Quality Terhadap Loyalitas Pelanggan Go-Jek Melalui Kepuasan Pelanggan. Agora, 4(2), 95-100.

15. Lakshmi, A. K. "The selfie culture: Narcissism or counter hegemony." Journal of Communication and media Studies (2015).

16. Nguyen-Phuoc, D. Q., De Gruyter, C., Nguyen, H. A., Nguyen, T., \& Ngoc Su, D. (2020). Risky behaviours associated with traffic crashes among app-based motorcycle taxi drivers in Vietnam. Transportation Research Part F: Traffic Psychology and Behaviour, 70, 249-259. https://doi.org/10.1016/j.trf.2020.03.010

17. Nguyen-Phuoc, D. Q., Oviedo-Trespalacios, O., Nguyen, T., \& Su, D. N. (2020). The effects of unhealthy lifestyle behaviours on risky riding behaviours - A study on app-based motorcycle taxi riders in Vietnam. Journal of Transport and Health, 16(April 2019), 100666. https://doi.org/10.1016/j.jth.2019.100666

18. Parasuraman, A., Berry, L. L., Zeithaml, V.A. (1985). A conceptual model of service quality and its implications for future research. Journal of Marketing, 49(4), 41-50.

19. Parasuraman, A., Berry, L. L., Zeithaml, V.A. (1988). SERVQUAL: a multiple item scale for measuring consumer perceptions of service quality. Journal of Retailing, 64(1), 12-37.

20. Ronia Pangaribuan, N., Sofia Wijaya, N. M., \& Eka Mahadewi, N. P. (2017). Faktor-Faktor Yang Mempengaruhi Keputusan Wisatawan Menggunakan Transportasi Berbasis Aplikasi Di Pt. Gojek Indonesia. Jurnal IPTA, 4(2), 64. https://doi.org/10.24843/ipta.2016.v04.i02.p13

21. Segoro, W. (2013). The Influence of Perceived Service Quality, Mooring Factor, and Relationship Quality on Customer Satisfaction and Loyalty. Procedia - Social and Behavioral Sciences, 81, 306-310. https://doi.org/10.1016/j.sbspro.2013.06.433

22. Septanto, H. (2016). Ekonomi Kreatif dan Inovatif Berbasis TIK ala Gojek dan Grabbike. Bina Insani ICT Journal, 3(1), 213219.

23. Septiani, R., Handayani, P. W., \& Azzahro, F. (2017). Factors that Affecting Behavioral Intention in Online Transportation Service: Case study of GO-JEK. Procedia Computer Science, 124, 504-512. https://doi.org/10.1016/j.procs.2017.12.183

24. Silalahi, S. L. B., Handayani, P. W., \& Munajat, Q. (2017). Service Quality Analysis for Online Transportation Services: Case Study of GO-JEK. Procedia Computer Science, 124, 487-495. https://doi.org/10.1016/j.procs.2017.12.181

25. Suatmadi, A. Y., Creutzig, F., \& Otto, I. M. (2019). On-demand motorcycle taxis improve mobility, not sustainability. Case Studies on Transport Policy, 7(2), 218-229. https://doi.org/10.1016/j.cstp.2019.04.005

26. Suhartanto, D., Dean, D., Gan, C., Chen, B. T., \& Michael, A. (2020). Case Studies on Transport Policy An examination of satisfaction towards online motorcycle taxis at diff erent usage levels. Case Studies on Transport Policy, (March 2019), 0-1. https://doi.org/10.1016/j.cstp.2020.04.008 
27. Wang, J. J., \& Lalwani, A. K. (2019). The distinct influence of power distance perception and power distance values on customer satisfaction in response to loyalty programs. International Journal of Research in Marketing, 36(4), 580-596. https://doi.org/10.1016/j.ijresmar.2018.11.006

28. Zeithaml, V. A., Parasuraman, A., Berry, L. L. (1996). The Behavioural Consequences of Service Quality. Journal of Marketing, 60(2), 31-46.

29. Zhang, C., Liu, Y., Lu, W., \& Xiao, G. (2019). Evaluating passenger satisfaction index based on PLS-SEM model: Evidence from Chinese public transport service. Transportation Research Part A: Policy and Practice, 120(December 2018), $149-164$. https://doi.org/10.1016/j.tra.2018.12.013 

